VOX PATRUM $26(2006)$ t. 49

Ks. Piotr SZCZUR

(Lublin, KUL)

\title{
PRZYCZYNY WYBORU I DEPOZYCJI JANA CHRYZOSTOMA Z URZĘDU BISKUPA KONSTANTYNOPOLA (Próba reinterpretacji przekazów historycznych)
}

Przystępując do badania wyboru antiocheńskiego prezbitera Jana na urząd biskupa Konstantynopola oraz pospiesznego odwołania go z tego urzędu, warto na wstępie zaznaczyć, iż teksty źródłowe, z których czerpiemy informacje na ten temat, koncentrują się na późniejszych wydarzeniach, które miały miejsce w Konstantynopolu w czasie episkopatu Jana. Ponadto wydaje się, iz źródłom tym brak jest obiektywizmu, oraz że skażone są „,interesami” poszczególnych autorów ${ }^{1}$. Efektem tego jest tendencja do przyjmowania w literaturze przedmiotu następującego schematu wydarzeń: 1. Jan został porwany z Antiochii (i dlatego stał się nic nie znaczącym pionkiem w rozgrywkach otaczających wybory); 2. nagle utracił łaski cesarzowej Eudoksji, mnichów z Konstantynopola oraz innych wpływowych ugrupowań (głównie z powodu radykalnych wymagań i naiwności politycznej); 3. zawiązał się przeciw niemu spisek pod przywództwem Akacjusza z Beroei ${ }^{2}$ i mnicha Izaaka $^{3}$, do których później

${ }^{1}$ Chodzi tu o następujące teksty źródłowe: Socrates, Historia ecclesiastica (= HE), ed. G.C. Hansen: Sokrates, Kirchengeschichte, GCS NF 1, Berlin 1995, przekł. pol. S.J. Kazikowski: Sokrates Scholastyk, Historia Kościoła, Warszawa 1986; Sozomenus, Historia ecclesiastica (= HE), ed. J. Bidez: Sozomenus, Kirchengeschichte, GCS NF 4, Berlin 1995, przekł. pol. S. Kazikowski: Hermiasz Sozomen, Historia Kościoła, Warszawa 1980; Theodoretus, Historia ecclesiastica (= HE), ed. L. Parmentier: Theodoret, Kirchengeschichte, GCS NF 5, Berlin 1998; Zosimus, Historia nova, ed. F. Paschoud: Zosime, Histoire nouvelle, I-III, Paris 1971-1989; Palladius, Dialogus de vita Ioannis Chrysostomi, ed. A.M. Malingrey - P. Leclercq: Palladios, Dialogue sur la vie de Jean Chrysostome, SCh 341-342, Paris 1988; Pseudo-Martyrius, Vita Iohannis Chrysostomi, PG 47. XLIII-LII (partim), transl. F. van Ommeslaeghe: De lijkrede voor Johannes Chrysostomus toegeschreven aan Martyrius van Antiochie. Textuitgave met Commentaar, Hoofdstukken uit de Historische Kritiek, Leuven 1974, 43-142; Philostorgius, Historia ecclesiastica, ed. J. Bidez - F. Winkelmann: Philostorgius, Kirchengeschichte, GCS 21, Berlin 1981.

${ }^{2}$ Palladiusz (Dialogus 6, SCh 341, 126) twierdzi, że wrogość Akacjusza wobec Jana spowodowana była słabym przyjęciem, z jakim spotkał się podczas pobytu w Konstantynopolu w 402 roku. Na temat Akacjusza por. A. Bober, Akacjusz z Beroei, EK I 207.

3 J.N.D. Kelly (Złote usta. Jan Chryzostom - asceta, kaznodzieja, biskup, tłum. K. Krakowczyk, Bydgoszcz 2001, 136) uważa, że powodem zatargu Jana z Izaakiem była chęć zmuszenia mnichów konstantynopolitańskich (z Izaakiem na czele) do kanonicznego posłuszeństwa biskupowi. 
dołączył Teofil z Aleksandrii; 4. w wyniku powstałej opozycji Jan nie był już w stanie uniknąć sytuacji, która doprowadziła go do drugiego i ostatecznego wygnania z Konstantynopola 20 czerwca 404 roku. Przedstawiony schemat przebiegu wydarzeń rzadko jest kwestionowany ${ }^{4}$, a dyskusja nad depozycją Jana na ogół koncentruje się na związkach pomiędzy poszczególnymi czynnikami sprawczymi wygnania. Zamierzeniem niniejszego artykułu jest próba zweryfikowania tego dobrze znanego obrazu (ocena czy jest on zgodny z rzeczywistością, czy też jest skonstruowany przez przeciwników lub zwolenników Jana) oraz spojrzenie na objęcie urzędu biskupa przez Jana w szerszym kontekście, zwłaszcza z perspektywy sytuacji panującej w Antiochii ${ }^{5}$.

\section{WYBÓR JANA NA BISKUPA KONSTANTYNOPOLA}

Jednym z najważniejszych źródeł do poznania działalności Jana Chryzostoma jest jego żywot Dialogus de vita Ioannis Chrysostomi, napisany przez Palladiusza. Trzeba jednak pamiętać, że pismo to ma charakter apologetyczny i hagiograficzny, oraz że zostało napisane przez przyjaciela i gorliwego obrońcę Jana $^{6}$. Z tego też względu analizując jego treść należy postawić kilka pytań: 1. Czy obraz nominacji i wyboru Jana na biskupa Konstantynopola przekazany przez Palladiusza jest rzetelny i obiektywny? 2. Czy właściwie jest odczytywany? 3. Czy jeśli spojrzy się na objęcie tronu biskupiego w Konstantynopolu w szerszym kontekście, zwłaszcza z perspektywy wydarzeń w Antiochii, obraz znacząco się zmienia? W niniejszym paragrafie spróbujemy wykazać, że szeroki kontekst historyczny wydarzeń, a zwłaszcza czynniki antiocheńskie, mają istotne znaczenie dla właściwego odczytania tego źródła.

Gdy bada się teksty źródłowe, mówiące o naciskach związanych z wyborem nowego biskupa Konstantynopola, które miały miejsce po śmierci biskupa

${ }^{4}$ Por. Ch. Baur, Johannes Chrysostomus und seine Zeit, Bd. II: Konstantinopel, Munich 1930; K. Holum, Theodosian empresses: women and imperial domination in late antiquity, Berkeley 1982, 69-78; J.H.W.G. Liebeschuetz, Barbarians and bishops: army, Church, and state in the age of Arcadius and Chrysostom, Oxford 1990, rozdz. XV-XXI; R. Brändle, Johannes Chrysostomus: Bischof - Reformer-Märtyrer, Stuttgart 1999, 54-132; Kelly, Ztote usta, s. 115-281.

5 Podobne badania, lecz dotyczące konfliktu pomiędzy Teofilem z Aleksandrii i Janem Chryzostomem, przeprowadziła Susanna Elm. Analizując wydarzenia historyczne w szerszym kontekście, a zwłaszcza z perspektywy wydarzeń mających miejsce w Aleksandrii, zweryfikowała tradycyjne spojrzenie na tę kwestię, por. jej: The Dog that did not bark. Doctrine and patriarchal authority in the conflict between Theophilus of Alexandria and John Chrysostom of Constantinople, w: Christian origins: theology, rhetoric and community, ed. L. Ayres - G. Jones, London 1998, 68-93.

6 Po wygnaniu Jana, Palladiusz wraz z przyjaciółmi Chryzostoma, udał się do Rzymu, by tam szukać pomocy. Po powrocie do Konstantynopola został uwięziony, a następnie skazany na wygnanie do Egiptu, gdzie przebywał do 412 roku. 
Nektariusza (27 IX 397) ${ }^{7}$, można zauważyć, że w Antiochii panowała przejmująca cisza w tej kwestii. Uwaga historyków omawiających te wydarzenia koncentruje się na zabiegach Aleksandryjczyków, reprezentowanych przez patriarchę Teofila († 412), pragnących obsadzić tron biskupi swym kandydatem aleksandryjskim prezbiterem Izydorem. Sokrates przekazuje następującą relację na ten temat:

\begin{abstract}
„Dla nadania sprawie ordynacji większej powagi przybył z polecenia cesarskiego, obok wielu innych biskupów, także i biskup Aleksandrii, Teofil, który za wszelką cenę chciał pomniejszyć sławę, jaką cieszył się Jan, i doprowadzić do wyboru na urząd biskupa Konstantynopola niejakiego Izydora, podległego mu prezbitera, którego szczególnie wyróżniał za to, że kiedyś podjął się w jego interesie realizacji niebezpiecznego zlecenia",
\end{abstract}

Odpowiedzią na działania Teofila był kontratak pałacu cesarskiego, reprezentowanego przez wszechpotężnego eunucha Eutropiusza $(† 399)^{9}$, usiłującego uniezależnić się od wpływów Aleksandrii ${ }^{10}$. Nigdzie nie wspomina się o zaangażowaniu Antiochii w rozgrywki poprzedzające wybór Jana na biskupa Konstantynopola. Można nawet odnieść wrażenie, że Antiochia w ogóle nie była zaangażowana w promowanie Jana jako kandydata na biskupa Nowego Rzymu, oraz że jego wybór był dla niej całkowitym zaskoczeniem, a od samego Jana oczekiwano, że będzie się wahał z przyjęciem tej nominacji ${ }^{11}$. Z powyższych przekazów wyłania się następujący obraz: skoro Aleksandria usiłowała obsadzić biskupstwo w Konstantynopolu swoim kandydatem, to wobec zaistniałej sytuacji eunuch Eutropiusz przedstawił Jana jako własnego kandydata na biskupa z powodów osobistych (trudno powiedzieć jakich ${ }^{12}$ ), nie sprawdzając, czy Jan w ogóle był zainteresowany tą nominacją.

Aby zrozumieć wagę przedstawionego wyżej punktu widzenia, należy przyjrzeć się zabiegom podejmowanym w czasie wyborów poprzedników Jana przez główne grupy zainteresowane biskupstwem w Konstantynopolu, tzn.

${ }^{7}$ Por. D. Stiernon, Nettario, DPAC II 2394; E. Reichert, Nektarios, w: Biographisch-biblographisches Kirchenlexikon, VI, ed. F.W. Bautz, Herzberg, 585-589.

${ }^{8}$ Socrates, HE VI 2, GCS NF 1, 312, Kazikowski s. 448.

9 Właściwie rozstrzygnięcie należało do cesarza, lecz decyzjami Arkadiusza (395-408) umiejętnie sterował Eutropiusz, który pełnił urząd praepositus sacri cubiculi.

${ }^{10}$ Por. Socrates, HE VI 2; Sozomenus, HE VIII 2; Theodoretus, HE V 27; Palladius, Dialogus 5.

11 Por. interpretację G. Dagron (Naissance d'une capitale. Constantinople et ses institutions de 330 à 451, Paris 1974, 464), a także J.N.D. Kelly'ego, który rozdz. VIII swej monografii (Złote usta, s. 115), zatytułował: „Niespodziewany awans” (w oryginale: „Unexpected promotion”).

${ }_{12}$ Palladiusz (Dialogus 5, SCh 341,112) sugeruje, że Eutropiusz, podczas podróży w sprawach państwowych na Wschód, wyrobił sobie pogląd na temat charakteru i zdolności Jana. J.N.D. Kelly stwierdza, że „to przypuszczenie ma znamiona prawdy, zwłaszcza jeśli [Eutropiusz - przyp. P. Sz.] dotarł z tą wizytą do Antiochii i jeśli zauważył, że Jan pełnił tam faktycznie obowiązki biskupa" (Ztote usta, s. 116). 
Rzym, Aleksandrię i Antiochię. Kiedy bada się procesy zachodzące wokół nominacji i wyboru Jana w kontekście wyboru jego poprzedników, należy zapytać, czy jest prawdopodobne, aby Antiochia była rzeczywiście tak oderwana od aktualnych wydarzeń, jak to sugeruje cisza w źródłach? Z jednej strony należy zauważyć, że do czasu wakatu po śmierci Nektariusza w 397 r., Konstantynopol stał się główną siłą we wschodniej polityce kościelnej, z drugiej zaś trzeba dostrzec, że Antiochia - jako jeden z najstarszych i najważniejszych ośrodków chrześcijaństwa wraz z Rzymem i Aleksandrią (blisko związanymi ze sobą) - od dawna była ważnym i aktywnym partnerem we wschodnich kręgach polityczno-kościelnych. Czy zatem sprawa wyboru biskupa Konstantynopola po śmierci Nektariusza była wyjątkiem w tym względzie? Czy Antiochia rzeczywiście była tylko biernym widzem na arenie wydarzeń jakie rozgrywały się w tym czasie?

1. Wybór Nektariusza (poł. 381 - 27 IX 397 r.). Jeśli prześledzi się wybór Nektariusza - bezpośredniego poprzednika Jana na stolicy w Konstantynopolu, to można zauważyć kilka istotnych czynników, które przedstawiają mechanizmy nacisków w podejmowaniu tej decyzji. Po pierwsze: jego nominacja i wybór były niespodzianką, ponieważ ugrupowanie aleksandryjsko-rzymskie z patriarchą Piotrem II Aleksandryjskim $(373-380)^{13}$ i papieżem Damazym $(366-384)^{14}$ na czele, zabiegało, by Grzegorz z Nazjanzu $(† 390)^{15}$ został uznany za osobę nieodpowiednią do objęcia urzędu biskupa Konstantynopola ${ }^{16}$, oraz aby to miejsce zajął cynik Maksym ${ }^{17}$, który z polecenia Piotra z Aleksandrii potajemnie został wyświęcony w Konstantynopolu przez kilku biskupów przybyłych z Egiptu ${ }^{18}$.

${ }^{13}$ Na temat Piotra, patriarchy Aleksandrii, por. M. Simonetti, Pietro II di Alessandria, DPAC II $2782-2783$.

${ }^{14}$ Na temat papieża Damazego zob. J.N.D. Kelly, Encyklopedia papieży, thum. i uzupełnienie T. Szafrański, Warszawa 2006, 52-54.

${ }^{15}$ Na temat Grzegorza por. F. Drączkowski, Grzegorz z Nazjanzu, EK VI 313-316.

16 Niechęć Piotra i Damazego wobec Grzegorza z Nazjanzu autor Wstępu (w: Święty Grzegorz z Nazjanzu, Mowy wybrane, praca zbiorowa, Warszawa 1967,13) tak komentuje: „Egipcjanie obawiali się, że stolica konstantynopolitańska pod rządami takiego biskupa zaćmi blask starej metropolii aleksandryjskiej. Damazy ze swej strony nie mógł się pogodzić z myślą, że przyjaciel Bazylego, i zwolennik Melecjusza, zwalczanego przez Rzym, zajmie drugą stolicę cesarstwa”.

${ }^{17}$ Na temat Maksyma por. Gregorius Presbyter, Vita S. Patris nostri Gregorii (Laudatio Gregorii Nazianzeni) 36-39, PG 35, 280-285, tłum. anonimowe: Żywot św. Grzegorza Teologa, biskupa Nazjanzu, spisany przez Grzegorza Prezbitera, w: Święty Grzegorz z Nazjanzu, Mowy wybrane, s. 43-45,

18 Por. Dagron, Naissance d'une capitale, s. 451-452; zob. też Wstęp, w: Święty Grzegorz z Nazjanzu, Mowy wybrane, s. 12: „Gdy na wiosnę 380 r., tuż przed Wielkanocą, cynicki filozof [Maksym - przyp. P. Sz.] wrócił do stolicy, z przyboczną gwardią marynarzy egipskich i grupą biskupów, zachowujących aż dotąd incognito, cała sprawa się wykryła. Pewnego poranka wierni przybywający do kościoła trafili na obrzędy wyświęcenia Maksyma na biskupa". 
Po drugie: należy odnotować, że osobą, która nominowała Nektariusza, był Diodor z Tarsu $(\dagger 394)^{19}$. Historyk Sozomen w następujący sposób opisuje tę sprawę:

„Przebywał wówczas w Konstantynopolu niejaki Nektarios, rodem z Tarsu w Cylicji, przedstawiciel prześwietnego stanu senatorskiego. Przygotowany już do podróży powrotnej do ojczyzny, przyszedł do Diodora, biskupa Tarsu, aby wziąć ze sobą listy, jeśliby oczywiście biskup zechciał takowe napisać. Trafił właśnie na moment, kiedy biskup pogrążony był w samotnych rozmyślaniach, kogo by tu należało wysunąć na kandydata do sakry, która poruszała tyle umysłów. I skoro tylko ujrzał Nektariosa, uznał, że jest to człowiek godny biskupiego urzędu; toteż w myśli z miejsca opowiedział się za jego kandydaturą, przypatrując się siwiźnie tego męża i postaci odpowiedniej dla biskupa, oraz biorąc pod uwagę jego miły sposób bycia" 20 .

W tym miejscu warto dodać, że Diodor był niegdyś liderem melecjańskonicejskiej fakcji w Antiochii, a w omawianym czasie (rok 381) był biskupem diecezji Tars, podległej Antiochii. Biorąc pod uwagę jego długi i bardzo bliski związek z Antiochią, wydaje się prawdopodobne, że w polityce kościelnej promował interesy tego miasta. Również Flawian († 404), nowy biskup Antiochii, wywodzący się z tej samej nicejskiej fakcji w Antiochii, który przewodził jej razem z Diodorem w okresie przebywania Melecjusza $(† 381)^{21}$ na wygnaniu $^{22}$, wspierał Diodora w promowaniu Nektariusza jako kandydata. Historyk Sozomen twierdzi, że Flawian początkowo wahał się z udzieleniem poparcia Nektariuszowi, ale ostatecznie dodał jego imię do listy kandydatów, co było przysługą oddaną Diodorowi:

„Niebawem, kiedy cesarz wydał biskupom polecenie, aby wszyscy - każdy na karcie - wypisali imiona tych wszystkich, jakich tylko uważają za godnych kandydatów do sakry, przy czym sobie samemu zastrzegł wybór spośród tej liczby jednego, każdy z biskupów zapisał kogo innego. Ale zwierzchnik Kościoła antio-

${ }^{19}$ Sokrates (HE V 8, GCS NF 1, 279-281, Kazikowski s. 402-403) nie wskazuje konkretnego imienia, lecz mówi, że Nektariusz został wybrany na powszechne życzenie: „Żył wówczas pewien człowiek imieniem Nektariusz, z rodu senatorskiego, nienagannych obyczajów, pod każdym względem godny podziwu i właśnie piastujący urząd pretora; on to, porwany przez ludność, wysunięty został jako kandydat na stolicę biskupią, a wyboru jego dokonało stu pięćdziesięciu obecnych wówczas biskupów".

${ }^{20}$ Sozomenus, HE VII 8, GCS NF 4, 310, Kazikowski s. 465.

${ }^{21}$ Na temat Melecjusza zob. M. Simonetti, Melezio di Antiochia, DPAC II 2205-2206.

22 Melecjusz jako biskup Antiochii był kilkakrotnie skazywany na wygnanie (m.in. w roku $359,365,369)$. Po raz pierwszy musiał opuścić swą stolicę biskupią w niecały miesiąc po objęciu urzędu, a dopiero po śmierci proariańsko nastawionego cesarza Walensa († 378), odzyskał na stałe swą stolicę biskupią, por. Joannes Chrysostomus, De sancto Meletio Antiocheno 1, PG 50, 516, tłum. W. Kania, PSP 8, 163-164; Sozomenus HE IV 28; Theodoretus, HE IV 22; zob. też J.M. Szymusiak, Grzegorz Teolog. U źródet chrześcijańskiej myśli IV wieku, Poznań 1965, 165, przypis 8; o Flawianie por. SWP 160. 
chijskiego wypisał imiona tych, których sam chciał wpisać, a na końcu całej listy, chcąc zrobić przyjemność Diodorowi, dopisał Nektariosa"23.

Po trzecie: Nektariusz, pomimo że był miejskim pretorem (praetor urba$n u s)^{24}$ w Konstantynopolu i członkiem senatu Nowego Rzymu ${ }^{25}$, miał też powiązania rodzinne w Tarsie. Wydaje się, że w momencie swej nominacji bliski był już przejścia na emeryturę, którą chciał spędzić w Tarsie ${ }^{26}$. Ścisłe więzi rodziny Nektariusza z diecezją Diodora oraz z Antiochią, wyraźnie sugerują, że Nektariusz był postrzegany jako kandydat wspierający interesy Antiochii w stolicy cesarstwa, a szczególnie interesy nicejskiej fakcji Flawiana (poprzednio Melecjusza). Ta okoliczność nabiera szczególnego znaczenia w świetle koalicji formujących się w trakcie schizmy antiocheńskiej. Studium działań podejmowanych przez obie fakcje wskazuje, że fakcja eustacjan, której w tym czasie przewodził Paulin $(\dagger 388)$, miała silne powiązania z Rzymem oraz biskupami Zachodu. Z powodu wspólnych interesów Rzymu i Aleksandrii, fakcja paulinistów (eustacjan) sprzymierzyła się również z Aleksandrią. Melecjanie natomiast mieli sprzymierzeńców wśród biskupów Wschodu oraz cieszyli się poparciem cesarza Teodozjusza Wielkiego $(† 395)^{27}$. Wybór kandydata popieranego przez Diodora i Flawiana, a co jest $\mathrm{z}$ tym związane przez melecjańsko-niecejską fakcję w Antiochii, oraz przez Teodozjusza, musiał wzbudzić poważną konsternację w Rzymie i Aleksandrii. Reakcją Zachodu na wydarzenia, które miały miejsce w Konstantynopolu, było natychmiastowe zwołanie synodu biskupów zachodnich (jeszcze w 381 r.) do Akwilei, któremu przewodniczył Ambroży z Mediolanu († 397). Na synodzie tym domagano się zwołania synodu ekumenicznego w Aleksandrii2 ${ }^{28}$, który miałby ocenić legalność wyboru Flawiana na stolicę w Antiochii (w rzeczywistości chodziło o podważenie ważności jego wyboru na korzyść Paulina) i zatwierdzić

${ }^{23}$ Sozomenus, HE VII 8, GCS NF 4, 310, Kazikowski s. 465.

24 Tytuł praetor urbanus oznaczał urzędnika zajmującego jedno z centralnych stanowisk w miejskiej prefekturze lub samego prefekta miasta, por. J. Sondel, Słownik łacińsko-polski dla prawników i historyków, Kraków 1997, 781: „Praetor urbanus - pretor miejski, wykonujący wladzę sądowniczą w sporach między obywatelami rzymskimi”; A. Jougan, Słownik kościelny łacińskopolski, Warszawa 1992, 536: „,praetor - 1. pretor, wyższy urzędnik z władzą wojskową; dowódca wojska, przełożony; 2. prefekt miasta; 3. burmistrz"; Słownik tacińsko-polski, red. M. Plezia, IV, Warszawa 1999, 275: „praetor - I. zwierzchnik, wódz, dowódca, naczelnik, przełożony; II. pretor (urzędnik rzymski następny godnością po konsulu), sędzia”; zob. też Dagron, Naissance d'une capitale, s. 239.

25 Por. Socrates, HE V 8; Sozomenus, HE VII 8.

26 Por. Sozomenus, HE VII 8; PLRE I 621 (Nectarius 2).

${ }^{27}$ Por. F. Cavallera, Le schisme d'Antioche (IVe-Ve siècle), Paris 1905, 262; W. Mayer, Antioch and the West in Late Antiquity, „Byzantinoslavica” 61 (2003) 5-32.

${ }^{28}$ Lokalizacja ta była nie do przyjęcia dla większości biskupów Wschodu. Również cesarz Teodozjusz nie poparł propozycji zwołania synodu w Aleksandrii. 
Maksyma Cynika, kandydata z Aleksandrii, jako prawowitego biskupa Konstantynopola $^{29}$. Istotne znaczenie może mieć też fakt, że Ambroży, pisząc o tych sprawach do Teodozjusza, oskarżał Nektariusza, którego uważał za nielegalnie osadzonego na stolicy w Konstantynopolu, o aktywne wspieranie i wyświęcenie Flawiana na biskupa Antiochii ${ }^{30}$ ! Połączone w ten sposób wątki wystarczająco wyraźnie sugerują, że nominacja i wybór Nektariusza - poprzednika Jana - nie były przypadkowe, lecz stanowiły istotny element polityki kościelnej Antiochii, a szczególnie fakcji melecjańsko-nicejskiej i miały dla nich wielką wagę ${ }^{31}$.

2. Wybór Eudoksjusza (360 - pocz. 370 r.). Opisany wyżej przypadek wyboru Nektariusza na biskupa Konstantynopola nie był odosobnionym wydarzeniem przedstawiającym wpływy Antiochii w polityce kościelnej Wschodu. Interesy antiocheńskie w sprawach związanych z biskupstwem w Konstantynopolu wyraźnie dają się zauważyć w roku 360, w okresie wakatu na stolicy konstantynopolitańskiej po depozycji biskupa Macedoniusza († ok. 364) $)^{32}$. Po śmierci antiocheńskiego biskupa Leoncjusza $(† 357 / 358)^{33}$, Eudoksjusz (który znaczną część życia spędził w Antiochii), nominowany z ramienia fakcji ariańskiej, objął urząd biskupa tego miasta. Zaś w styczniu 360 r., po depozycji Mecedoniusza, dzięki zabiegom arian został osadzony na stolicy w Konstantynopolu ${ }^{34}$. Interesujący w całej sprawie jest fakt, że Eudoksjusz na kilka miesięcy przed objęciem urzędu biskupa Konstantynopola został pozbawiony urzędu biskupa Antiochii na synodzie w Seleucji Izauryjskiej (359), zorganizowanym przez zwolenników Macedoniusza - ówczesnego biskupa Konstantynopola ${ }^{35}$, którego miał wkrótce

${ }^{29}$ Por. Ambrosius, Epistula extra collectionem VI (XII), ed. M. Zelzer, CSEL 82/3, 186-190; tenże, Epistula extra collectionem IX (XIII), CSEL 82/3, 201-204; zob. N.B. McLynn, Ambrose of Milan: Church and court in a Christian Capital, Berkeley 1994, 137-146.

${ }^{30}$ Por. Ambrosius, Epistula extra collectionem IX (XIII), CSEL 82/3, 201-202.

31 J.N.D. Kelly przedstawia inną interpretację faktów związanych z wyborem Nektariusza. Na pierwszy plan wysuwa dążenia cesarza Teodozjusza I twierdząc, że „,[...] był to przemyślany wybór, ponieważ w Konstantynopolu dominował w owym czasie arianizm, i cesarz, zdecydowany przyciągną́ miasto w stronę nicejskiej ortodoksji, z którą sam był związany, słusznie uznał, że osoba popularnego dyplomaty, takiego jak Nektariusz, osiągnie to łatwiej niż nieprzejednany dogmatyk" (Ztote usta, s. 115-116).

${ }^{32} \mathrm{Na}$ temat Macedoniusza por. M. Simonetti, Macedonio, DPAC II 2062; J. Naumowicz, Macedoniusz I, EK XI 682.

${ }^{33}$ Na temat Leoncjusza por. M. Szram, Leoncjusz z Antiochii, EK X 794.

${ }^{34}$ Por. Dagron, Naissance d'une capitale, s. 443-444; P. Maraval, Le christianisme de Constantin à la conquête arabe, Paris 1997, 92.

${ }^{35}$ Por. Sozomenus, HE IV 22 - gdzie autor podaje niekompletną listę biskupów zdeponowanych przez synod, wśród których wymieniony jest Eudoksjusz, biskup Antiochii; Sokrates (HE II 40, Kazikowski s. 253), który również podaje listę usuniętych biskupów, mówi, że usunięto też „Eudoksjusza, który poprzednio był biskupem Germanicji, a później wśliznął się na tron biskupi Antiochii Syryjskiej”; zob. też Dagron, Naissance d'une capitale, s. 443. 
zastąpić $^{36}$. W świetle zestawienia rozmieszczenia geograficznego stolic biskupów zdeponowanych z Eudoksjuszem w 359 r. na synodzie w Seleucji oraz złożonych z urzędu wraz z Macedoniuszem w 360 r. na synodzie w Konstantynopolu, Gilbert Dagron postrzega przedstawione wydarzenia jako przejaw umacniania się wpływów diecezji Oriens, a szczególnie jej stolicy w Antiochii ${ }^{37}$.

Zatem w dwóch przypadkach wyboru biskupów Konstantynopola - przed wyborem Jana Chryzostoma - daje się zauważyć, jak w trudnych dla episkopatu momentach wpływy antiocheńskie uzyskiwały decydujący głos we wspólnocie chrześcijańskiej Konstantynopola.

3. Rosnący status polityczno-kościelny Konstantynopola. Wracając do wyborów Nektariusza i Jana Chryzostoma na biskupów konstantynopolitańskich, należy zauważyć, że istotnym składnikiem rozgrywek kościelno-politycznych był rosnący status stolicy biskupiej w Konstantynopolu ${ }^{38}$. Punktem kulminacyjnym był trzeci kanon Soboru Konstantynopolitańskiego (381), który przyznawał szczególną pozycję Nowemu Rzymowi. Ojcowie Soborowi orzekli, że „Biskup Konstantynopola powinien mieć honorowe pierwszeństwo po biskupie Rzymu, ponieważ to miasto jest Nowym Rzymem"39. Gilbert Dagron odnotowuje, że w okresie półtora roku (od wstąpienia na tron cesarza Teodozjusza Wielkiego do zamknięcia II Soboru Powszechnego w 381 r.) Konstantynopol - Nowy Rzym, zastąpił w roli centrum zjednoczonego Kościoła dominujące do tego czasu stolice biskupie: Rzym i Aleksandrię ${ }^{40}$.

Jeśli weźmie się pod uwagę ten czynnik, stanie się jasne, że Aleksandria by nie stracić swych wpływów i znaczenia - musiała podejmować różne zabiegi w czasie wyboru Nektariusza, a kiedy po jego śmierci w Konstantynopolu zaistniał kolejny wakat, zależało jej na przejęciu kontroli nad tak ważną stolicą. Z tego też względu Teofil Aleksandryjski nie tylko zabiegał o wybór swego kandydata, lecz także był zdecydowanie przeciwny wyborowi kolejnego kandydata pozytywnie ustosunkowanego do melecjańsko-nicejskiej fakcji z Antio-

${ }^{36}$ Por. Socrates, HE II 43, GCS NF 1, 180, Kazikowski s. 259: „Wtedy zaś, po usunięciu Macedoniusza, Eudoksjusz, uważający tron biskupi Antiochii za coś podrzędniejszego, zostaje wyznaczony na biskupa Konstantynopola, przy czym intronizację przeprowadzili zwolennicy Akacjusza, których uwagi zupełnie uszedł fakt, że podejmują decyzję sprzeczną z tym, co sami uchwalili".

${ }^{37}$ Por. Naissance d'une capitale, s. 443-444: „Si bien que, quand on voit Eudoxe d'Antioche supplanter Makédonios à Constantinople, on a un peu l'impression que c'est l'Orient qui s'empare de la capitale à la faveur d'un schisme; l'Orient d'Antioche et non celui de Constantinople".

38 Istotną datą w historii Konstantynopola jest dzień 11 grudnia 359 r., gdy cesarz Konstancjusz II (337-361) mianował niejakiego Honorata prefektem Konstantynopola i zawiesił władzę prokonsulów. Tym samym Konstantynopol ostatecznie został zrównany z Rzymem, zarządzanym przez prefektów od czasów Augusta († 14), por. Socrates, HE II 41.

${ }^{39}$ I. Concilium Constantinopolitanum can. 3, DSP I [ŹMT 24] 72-73.

${ }^{40}$ Por. Naissance d'une capitale, s. 454-455. 
chii. Ponadto, kiedy weźmie się pod uwagę fakt, że kandydat, który odniósł sukces, nie pochodził ze stronnictwa rzymsko-aleksandryjskiego, ale był protegowanym Flawiana oraz członkiem fakcji, której Flawian przewodził ${ }^{41}$, to widać, że interesy Aleksandrii poniosły znaczny uszczerbek. Jeśli spojrzy się na wydarzenia w tym świetle, to wydaje się być mało prawdopodobne, że nominacja i wybór Jana były przypadkowe oraz, że Antiochia, a szczególnie kierowana przez Flawiana fakcja nicejska, były - jak chcą źródła - politycznie neutralne, a nawet zupełnie wyłączone z tej kwestii. Faktem potwierdzającym zainteresowanie Jana sprawami melecjańsko-nicejskiej fakcji w Antiochii i sugerującym, że jego wybór nie był przypadkowy, jest to, że pierwszym przedsięwzięciem Jana, w którym wykorzystał autorytet dany mu przez objęcie urzędu biskupa tak ważnej stolicy, było zwrócenie się do Rzymu z prośbą o potwierdzenie wyboru Flawiana na biskupa Antiochii, oraz o aprobatę roszczenia wysuwanego przez fakcję, którą popierał i wobec której był lojalny, by została uznana za prawowity, ortodoksyjny Kościół nicejski w tym mieście. Sozomen omawiając te wydarzenia pisze:

„,[...] kiedy [Jan - przyp. P. Sz.] objął urząd episkopalny, a biskupi w Egipcie i na Zachodzie byli jeszcze z powodu Paulina poróżnieni z biskupami na Wschodzie, i na całym obszarze państwa utrzymywała się w związku z tym pomiędzy poszczególnymi Kościołami jakaś ogólna niechęć do wzajemnych kontaktów, Jan poprosił Teofila, by przystąpił do wspólnego z nim działania i pojednał rzymskiego biskupa z Flawianem" 42 .

Przedstawione powyżej fakty i ich interpretacja, prowadzą do wniosku, że obraz wydarzeń związanych z wyborem Jana na biskupa Konstantynopola, jaki przekazują źródła, jest albo realizacją literackiego toposu skromności Jana, albo wynika z chęci retuszowania faktów, które odbierałyby chwałę ulubionemu wizerunkowi episkopatu Chryzostoma, budowanemu szczególnie przez Palladiusza i Pseudo-Martyriusza.

\section{EPIFANIUSZ Z SALAMINY WOBEC JANA CHRYZOSTOMA}

W badaniu i interpretacji wydarzeń z czasów episkopatu Jana może pomóc analiza jeszcze innej kwestii, mianowicie jego kontaktów z Epifaniuszem, bisku-

${ }^{41}$ Por. W. Mayer, Patronage, pastoral care and the role of the bishop at Antioch, VigCh 55 (2001) 61 i 63 .

${ }^{42}$ Sozomenus, HE VIII 3, GCS NF 4, 353, Kazikowski s. 526. Należy też zauważyć, że Teodoret z Cyru (HE V 23) pisze, że to Flawian wysłał poselstwo do Rzymu. Jednak bez względu na to, czy to Jan wysłał poselstwo, czy też inicjatywa pochodziła od Flawiana, jest jasne, że wstąpienie na tron biskupi w Konstantynopolu antiocheńskiego kandydata z melecjańskiej fakcji miało pierwszorzędne znaczenie, por. Kelly, Złote usta, s. 129. 
pem Salaminy na Cyprze $(† 403)^{43}$. W tym przypadku źródła także kreują jeden obraz, jednak na podstawie studium kontekstu wydarzeń można przyjąć zupełnie inną interpretację faktów. Aby tę kwestię wyjaśnić należy postawić kilka pytań: co skłoniło Epifaniusza z Salaminy do tak ochoczego sprzymierzenia się z wrogami Jana? A zwłaszcza: co sprowokowało go do tak wrogiego zachowania, jakie zaprezentował po przybyciu do Konstantynopola w poł. 402 roku? Przyjazd Epifaniusza do Konstantynopola opisują dwaj historycy Sokrates i Sozomen:

„Wkrótce potem do Konstantynopola ponownie przybył z Cypru biskup Epifaniusz [...]. Skoro zatem wylądował w pobliżu bazyliki Jana [...] i wyszedł na brzeg, odprawił nabożeństwo i wyświęcił diakona, po czym niezwłocznie wyjechał do stolicy. Chcąc zaś wyświadczyć przysługę Teofilowi, uchylił się od przyjęcia zaproszenia od Jana: gościł w mieszkaniu prywatnym. [...] Jan nie oburzył się na to, że Epifaniusz wbrew regule kościelnej udzielił święceń na terenie jego Kościoła, co więcej zaprosił go, żeby zamieszkał razem z nim w siedzibie biskupiej. Ten jednakże odmówił zarówno korzystania $\mathrm{z}$ jego gościny, jak i współudziału w nabożeństwach, o ile Jan nie usunie z miasta Dioskora wraz z towarzyszącymi mu duchownymi i nie złoży swego podpisu pod uchwałą wyklinającą dzieła Orygenesa"44.

„Wnet zatem Epifaniusz, jako pierwszy wypłynąwszy z Cypru, zawinął do tak zwanego siódmego rejonu, leżącego tuż u bram Konstantynopola. Odbywszy oczywiście modły w tamtejszym kościele, wkroczył do miasta. Przy wejściu uczcił go Jan, wychodząc mu naprzeciw razem z całym duchowieństwem. Epifaniusz niedwuznacznie okazywał swoim zachowaniem, że dał wiarę godzącym w Jana zarzutom; zaproszony bowiem na wstępie, by się zechciał zatrzymać w kwaterach kościelnych, zaproszenie odrzucił. Od spotkania z Janem zdecydowanie się uchylił, ale na własną rękę zwołując biskupów bawiących w Konstantynopolu, zapoznał ich z treścią uchwał, podjętych przeciwko rozprawom Orygenesa” ${ }^{, 45}$.

Postępowanie Epifaniusza jest szczególnie zastanawiające, jeśli zauważy się, że nie miał on okazji, by wątpić w ortodoksję Jana. Zarówno Ch. Baur, jak i J. N. D. Kelly zachowanie to tłumaczą połączeniem dwóch czynników: złośliwego podburzania Epifaniusza przez Teofila oraz pragnienia Epifaniusza, by wykorzenić wszelkie herezje. Wspomniani autorzy precedens takiego postępowania widzą w spotkaniu Epifaniusza z Janem, biskupem Jerozolimy $(† 417)^{46}$, które miało miejsce dziesięć lat wcześniej (393) w Jerozolimie ${ }^{47}$. Wydaje się jednak,

${ }^{43}$ Na temat Epifaniusza zob. C. Riggi, Epifanio di Salamina, DPAC I 1162-1164; F. Drączkowski, Epifaniusz, EK IV 1021-1023.

44 Socrates, HE VI 12 i 14, GCS NF 1, 333, 335, Kazikowski s. 415+416, 418. Na ten temat zob. Kelly, złote usta, s. 219-224.

45 Sozomenus, HE VIII 14, GCS NF 4, 368, Kazikowski s. 549-550.

${ }^{46} \mathrm{Na}$ temat Jana Jerozolimskiego por. D. Stiernon, Jean de Jerusalem, DSp VIII 565-574; H. Pietras, Jan II Jerozolimski, EK VII 904-905.

47 Por. Baur, Johannes Chrysostomus und seine Zeit, Bd. II, rozdział XX; Kelly, Złote usta, s. 220-221; zob. też Brändle, Johannes Chrysostomus, s. 111, który prezentuje identyczne stano- 
że żaden $\mathrm{z}$ argumentów nie daje satysfakcjonującego wyjaśnienia. Interesujące jest, że zarówno J. N. D. Kelly ${ }^{48}$, jak i R. Brändle ${ }^{49}$, wątpią w to, że Teofil był przekonany, iż teologia Jana była skażona orygenizmem, a jednocześnie nie mają trudności z przyjęciem prezentowanego przez źródła przebiegu wydarzeń związanych z działalnością Epifaniusza, mianowicie tego, że oskarżenia kierowane przez Teofila pod adresem Jana uważał za uzasadnione i czuł się zobowiązany do podjęcia szybkich kroków w celu zapobieżenia rozprzestrzeniania się herezji. Ch. Baur przypomina, że dziesięć lat wcześniej, Teofil nie popierał postępowania Epifaniusza wobec Jana z Jerozolimy, a nawet je potępił. Pojawia się więc kolejne pytanie: jak Teofil mógł oczekiwać, że Epifaniusz teraz go wesprze?

Wydaje się, że klucz do interpretacji tych wydarzeń kryje się w schizmie antiocheńskiej i koalicjach formowanych przez obie fakcje nicejskie. J. N. D. Kelly $^{50}$ i R. Brändle ${ }^{51}$ mimochodem wskazują na to, jako na czynnik sprawczy, ale żaden $\mathrm{z}$ nich nie wykazuje, jak silny był związek pomiędzy Paulinem liderem fakcji eustacjan - a Epifaniuszem. Pierwszy godny odnotowania fakt jest następujący: Aleksandria nie była osamotniona wśród wschodnich diecezji w walce toczonej wspólnie z Zachodem przeciw akceptacji roszczenia Flawiana co do stolicy w Antiochii. Razem z Aleksandrią i Rzymem, sprawę Paulina poparł Cypr ${ }^{52}$. Drugim istotnym faktem jest - jak wspomina Hieronim - przebywanie (z powodów polityczno-kościelnych) Epifaniusza i Paulina w Rzymie w tym samym czasie i wspólne odbycie statkiem podróży powrotnej do swych diecezji, w towarzystwie rzymskiej matrony Pauli ${ }^{53}$. Po dotarciu do Salaminy podróż opóźniła się, gdyż Paula i Paulin skorzystali z gościnności Epifaniusza, co sugeruje bardziej zażyłą znajomość. Jeśli więc przyjmie się, że Epifaniusz aktywnie wspierał roszczenia Paulina, to jeszcze raz należy zauważyć, że osadzenie na tronie biskupim w Konstantynopolu Jana, kapłana z fakcji Flawiana, musiało spowodować wielkie niezadowolenie Epifaniusza. Jest zatem możliwe,

wisko. Na temat starcia Epifaniusza z Janem z Jerozolimy por. J.N.D. Kelly, Hieronim. Życie, pisma, spory, tłum. R. Wiśniewski, Warszawa 2003, 228-230.

48 Por. Złote usta, s. 219.

49 Por. Johannes Chrysostomus, s. 111.

${ }^{50}$ Por. Ztote usta, s. 218.

51 Por. Johannes Chrysostomus, s. 111.

52 Pisząc o synodzie konstantynopolitańskim, który miał miejsce w poł. 382 r. Sokrates (HE V 10, Kazikowski s. 408) przekazuje następującą informację: „Przedstawiciele Egiptu, Arabii i Cypru tworząc opozycję żądali usunięcia Flawiana z Antiochii”. Natomiast Sozomen (HE VII 11, Kazikowski s. 471) komentując wyświęcenie Flawiana na biskupa Antiochii i związane z tym wydarzeniem podziały wśród wiernych, pisze: „Poróżnili się na tym tle między sobą również i inni biskupi. I tak oto pasterze Kościoła Egiptu, Arabii i Cypru nie posiadali się z oburzenia, uważając, że krzywda spotkała Paulina”.

53 Podróż ta miała miejsce w 385 r.; por. Kelly, Hieronim, s. 226; Hieronymus, Epistula 108, 6-7, CSEL 55, 310-313, tłum. J. Czuj: Św. Hieronim, Listy, II, Warszawa 1953, 418-420. 
że Epifaniusz udzielając poparcia Paulinowi (jak uczynił to Teofil), dla osiągnięcia wspólnego celu, jakim było zdyskredytowanie Jana, zapomniał o dawnym afroncie ze strony Teofila. Jest to szczególnie prawdopodobne, jeśli weźmie się pod uwagę fakt, że Jan otrzymał poparcie Rzymu, do tego czasu kluczowego sprzymierzeńca Aleksandrii i Cypru w sprawie Paulina. Należy też dodać, że podczas poprzednich wizyt w Konstantynopolu Epifaniusz korzystał z gościnności ${ }^{54}$ i funduszy Olimpii ${ }^{55}$, co Jan również zmienił ${ }^{56}$. Jak widać, promowany przez źródła wizerunek Epifaniusza jako świątobliwego i gorliwego pogromcy heretyków, nabiera nieco innych barw. Możliwe jest, że zafałszowana relacja Teofila, dotycząca związków Jana z Długimi Brać$\mathrm{mi}^{57}$, których Chryzostom przyjął życzliwie w Konstantynopolu, zadziałała jak iskra powodująca wybuch wrogości ${ }^{58}$, jednak w świetle przedstawionych wyżej faktów można stwierdzić, że korzenie wrogości Epifaniusza względem Jana leżały znacznie głębiej, a wrogość ta miała okazję, by rozwijać się przez długi czas.

\section{DUSZPASTERSTWO JANA W ANTIOCHII I W KONSTANTYNOPOLU}

Trzecie i ostatnie pytanie, jakie warto postawić, brzmi: dlaczego Jan nie popadł w kłopoty, jakie spotkały go w Konstantynopolu, w okresie pracy duszpasterskiej w Antiochii? Jeśli, jak sugerują źródła, jego osobowość, hierarchia wartości, styl życia i dążenia miały taki charakter, że szybko przyczyniły się do wejścia w konflikt $\mathrm{z}$ duchowieństwem, kobietami, mnichami i arystokracją Konstantynopola, to dlaczego te same cechy nie stały się przyczyną konfliktu $\mathrm{z}$ analogicznymi grupami $\mathrm{w}$ Antiochii? Czyżby znowu zaangażowanie źródeł miało mylący wpływ na obiektywne spojrzenie na posługę duszpasterską Jana w obu miastach? Źródła prezentują dość jednolity obraz działalności Jana pod-

${ }_{54}^{5}$ Por. Kelly, Zlote usta, s. 124.

55 O fortunie Olimpii J.N.D. Kelly (Złote usta, s. 123) pisze: ,Jako wywodząca się z arystokracji wnuczka Ablabiusza, prefekta pretorianów za rządów Konstantyna, Olimpia była bajecznie bogata. Posiadała dobra w Tracji, Galacji, Kapadocji i Bitynii, a także wiele majątków w samym Konstantynopolu". Szerzej na jej temat zob. Palladius, Dialogus 10, 16, 17, SCh 341, 207-209, 319331, 349; tenże, Historia Lausiaca 56 (ed. G.J.M. Bartelink: Palladio, La Storia Lausiaca, Milano 1974, 252, tłum. S. Kalinkowski: Palladiusz, Opowiadania dla Lausosa (Historia Lausiaca), ŹM 12 , Kraków 1996, 211-212; anonimowe Vita Sanctae Olympiadis (ed. A.M. Malingrey: Vie anonyme d'Olympias, SCh 13bis, Paris 1968, 406-449); R. Janin, Olimpia, BS IX 1154-1158.

56 Por. Palladius, Dialogus 17, SCh 341, 348; zob. tamże 16, SCh 341, 320-322, gdzie Palladiusz twierdzi, że Teofil także próbował uzyskać pieniądze od Olimpii. W tym samym fragmencie odnosi się do ambiwalentnego stosunku Teofila do Epifaniusza.

${ }^{57}$ Por. Socrates, HE VI 7-10 i 16-17; Sozomenus, HE VI 30 i VIII 11-17; J. Misiurek, Bracia dłudzy, EK II 994-995; Kelly, Złote usta, s. 205-215.

${ }^{58}$ Por. Kelly, Złote usta, s. 210-213. 
czas dwunastu lat, gdy był antiocheńskim prezbiterem (386-397), podkreślając właściwie jedynie jego dobrą wolę i harmonię panującą pomiędzy nim i innymi ludźmi. Palladiusz wymienia kilka pozytywnych dokonań duszpasterskich Jana, a podsumowując pisze: „Tak więc [wszystko było] pomyślną żeglugą pod sterem Chrystusa" ${ }^{59}$. Pseudo-Martyriusz natomiast zdaje eulogiczną relację z energicznej posługi Jana w Antiochii ${ }^{60}$. Z kolei Teodoret z Cyru pomija lata poprzedzające przybycie Jana do Konstantynopola ${ }^{61}$. Zaś Sokrates oferuje bezstronny komentarz co do mniej kontrowersyjnych aspektów charakteru Jana, ale już nie posuwa się do analizy ich wpływu na jego posługę w Antiochii. Mówi:

„Podobno Jan był człowiekiem nieco ostrym w obejściu z powodu gorliwości w umartwianiu się i, jak powiedział ktoś bardzo z nim zżyty od najmłodszych lat, więcej serca poświęcał gniewnemu uniesieniu, aniżeli duchowi przebaczenia: walcząc o prawość życia nie ubezpieczał się na przyszłość, a w prostocie serca był przystępny i nieostrożny. Nie znał też miary w swobodnym wypowiadaniu się wobec każdego; kiedy nauczał, pragnął przede wszystkim korzystnie wpłynąć na moralność słuchaczy. Ci, którzy nie znając go, przypadkowo się z nim zetknęli, odnosili wrażenie, że skłonny jest do samochwalstwa" ${ }^{12}$.

Jedynie historyk Sozomen wprowadza nutę negatywnej oceny Chryzostoma, kiedy pisze, że w Antiochii odwaga Jana cieszyła lud (z kontekstu wynika, że Sozomen odnosi się tu do kazań głoszonych przez Jana), ale martwiła bogatych i mających władzę, przeciwko którym była wymierzona:

„[Jan - przyp. P. Sz.] pozyskał sobie także i pospólstwo, zwłaszcza że niejednokrotnie gromił przewiny zatwardziałych grzeszników, zarówno przemawiając w kościele, jak i odważnie rzucając słowa oburzenia prosto w oczy tych, co wyrządzają krzywdę; przy czym oburzał się tak, jakby to on sam właśnie padł ofiarą krzywdzącego czynu. Ta okoliczność była niewątpliwie czymś miłym dla najszerszych warstw społeczeństwa; ale dla bogaczy i dla możnych tego świata, których obciąża mnóstwo przewinień - czymś niepokojącym”63.

W kontekście wypowiedzi Sozomena należy zauważyć, że jeśli dokładnie analizuje się zawartość i styl kazań Jana Chryzostoma, to nie zauważa się żadnej istotnej różnicy w tonie i treści pomiędzy homiliami wygłoszonymi we wcześniejszym lub późniejszym okresie, czyli między tymi, które wygłosił w Antiochii, gdy był prezbiterem, a tymi, które wygłosił w Konstantynopolu, gdy był biskupem ${ }^{64}$.

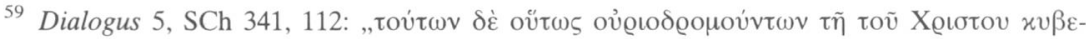

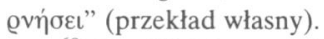

${ }^{60}$ Por. W. Mayer, John Chrysostom as Bishop: The View from Antioch, JEH 55 (2004) 461.

${ }^{61}$ Por. HE V 27; Teodoret rozpoczyna swoją relację od święceń biskupich Jana.

62 Socrates, HE VI 3, GCS NF 1, 315, Kazikowski s. 452.

${ }^{63}$ Por. Sozomenus, HE VIII 2, GCS NF 4, 351, Kazikowski s. 523-524.

${ }^{64}$ Por. Mayer, John Chrysostom as Bishop, s. 462: „[...] when the content and style of John's preaching are carefully analysed, there is no noticeable difference in tone or content between those 
W jego przekonaniu obowiązki wynikające ze święceń kapłańskich, właściwie były takie same, jak te, które wynikały ze święceń biskupich, i w zasadzie nie widział on żadnej różnicy pomiędzy rolą prezbitera i biskupa ${ }^{65}$. Obecnie uczeni przyjmują bez zastrzeżeń, że to, co w przeszłości uważano za tzw. „ton episkopalny" w przepowiadaniu Jana - czyli mocne krytykowanie i potępianie niektórych wad członków wspólnoty kościelnej i często towarzysząca temu groźba wykluczenia winnych z Kościoła - w rzeczywistości jest obecne zarówno w homiliach głoszonych w Antiochii, jak i Konstantynopolu ${ }^{66}$. Jeśli więc zaakceptuje się powszechnie przyjmowaną tezę, że w Konstantynopolu treść homilii wygłaszanych przez Jana obrażała słuchaczy, do których były skierowane ${ }^{67}$, to należy też zaakceptować prawdziwość komentarza Sozomena, że ten sam styl kazań był obraźliwy dla bogatych i wpływowych słuchaczy w Antiochii ${ }^{68}$.

Po drugie, Jan najprawdopodobniej był przygotowywany przez Flawiana na jego następcę w Antiochii ${ }^{69}$. Nie wiemy dokładnie, kiedy zaczął się ten proces, ale rozsądne wydaje się przypuszczenie, że Jan zajmował się sprawami de facto episkopalnymi w ciągu kilku lat poprzedzających jego wybór na biskupa Konstantynopola. Taka interpretacja wydarzeń ma trzy konsekwencje. Po pierwsze, Jan już przed przybyciem do stolicy cesarstwa miał w pełni rozwinięte pojęcie o tym, co wiąże się z rolą biskupa. Tę wizję episkopatu ukształtowały lata służby w melecjańsko-nicejskiej fakcji w Antiochii, pod przywództwem najpierw Melecjusza ${ }^{70}$, a później Flawiana. Drugą konsekwencją jest to,

homilies preached during his presbyterate, whether early or late, and those which belong to his episcopate"; zob. też tenże, The Homilies of St John Chrysostom: provenance, reshaping the foundations, OCA 273, Rome 2005, 315-473.

${ }^{65}$ Por. In epistulam I ad Timotheum hom. 11, 1, PG 62, 553, thum. T. Sinko: Św. Jan Zlotousty, Homilie na Listy pasterskie św. Pawła i na List do Filemona, Kraków 1949, 111: „[...] między prezbiterami a biskupami nie ma wielkiej odległości, skoro i tamci otrzymali obowiązek nauczania i przełożeństwo nad Kościołem; co więc [Paweł - przyp. P. Sz.] powiedział o biskupach, to samo przystaje także do prezbiterów. Owi górują nad nimi tylko ordynacją i przez to jedynie, jak się zdaje, więcej znaczą od prezbiterów".

${ }^{66}$ Por. P. Allen - W. Mayer, Chrysostom and the preaching of homilies in series. A new approach to the twelve homilies "In epistulam ad Colossenses” (CPG 4433), OCP 60 (1994) 2139, zwł. 24-27; Mayer, The Homilies of St John Chrysostom, s. 331-336.

${ }^{67}$ Por. Kelly, Złote usta, s. 148-149; Liebeschuetz, Barbarians, s. 176-177.

68 Wzmianki o problemach, jakie przeżywał Jan, podczas gdy był prezbiterem, prowadzą do kwestii początkowej, czyli nominacji i wyboru Jana na biskupa. Warto zapytać: czy mogło być tak, że oprócz tego, że nominacja Jana była strategicznym posunięciem z punktu widzenia interesów melecjańsko-nicejskiej fakcji w Antiochii, była również promowana przez należących do tej samej fakcji majętnych i wpływowych członków wspólnoty antiocheńskiej? Być moze bogaci arystokraci, zirytowani charakterem, zachowaniem i kazaniami Jana, użyli swych wpływów, aby zapewnić ochronę interesów swej fakcji i tym samym, na zawsze pozbyć się Jana z Antiochii? W tym kontekście jego awans byłby postrzegany jako „uwolnienie” miejscowej wspólnoty od niewygodnego duszpasterza.

${ }^{69}$ Por. Mayer, Patronage, pastoral care, s. 58-70.

70 J.N.D. Kelly (Złote usta, s. 28-30 i 48-49) przypuszcza, że Jan był bardzo bliskim współpracownikiem Melecjusza. Pisze (tamże, s. 29) tak: „możemy domniemywać, że pracował on [Jan - 
że Jan musiał być świadomy kościelnych i politycznych napięć związanych z pozycją biskupa, zajmowaną bądź w Antiochii, bądź w Konstantynopolu. Przecież jego wizja episkopatu kształtowała się w okresie, kiedy skomplikowane i ciągle zmieniające się alianse polityczne (obejmujące wówczas z jednej strony Syrię, Palestynę i Azję Mniejszą, z drugiej zaś - Aleksandrię i Rzym) były niezwykle ważne dla posiadających wówczas w Antiochii znaczenie trzech lub czterech chrześcijańskich fakcji ${ }^{71}$. Trzecią konsekwencją jest to, że poprzez zaangażowanie w wypełnianie obowiązków episkopalnych ${ }^{72}$, naturalnie gorliwy i autorytatywny charakter Jana mógł zyskać dodatkowe możliwości manifestacji tych $\operatorname{cech}^{73}$. Jest więc prawdopodobne, że w późniejszych latach działalności w Antiochii, indywidualne relacje Jana $\mathrm{z}$ wiernymi podlegały tym samym napięciom, jakie później można zaobserwować w Konstantynopolu. Szczególne znaczenie w tej kwestii ma rozsądne założenie, że takie relacje w Antiochii dotyczyły przede wszystkim członków miejscowej arystokracji i ludzi ze sfer wyższych, a nie z niższych warstw społecznych. A jeśli w rzeczywistości tak było, to już w Antiochii pojawiały się te same składniki konfliktu, które następnie można odnaleźć w Konstantynopolu, mianowicie chodzi tu o kazania, które antagonizowały wpływowych i bogatych ludzi, poparte niezbyt dyplomatycznymi stosunkami prywatnymi z osobami z tych samych warstw społecznych.

Skoro w charakterze Jana, w stylu głoszonych kazań oraz w wypełnianiu funkcji episkopalnych w Antiochii i w Konstantynopolu w zasadzie nie widać istotnych różnic, to w tym miejscu należy zadać kilka pytań: dlaczego Chryzostom nie popadł w poważne kłopoty w Antiochii tylko w Konstantynopolu, gdzie przecież działał znacznie krócej? Jakie czynniki łagodzące zaistnienie konfliktu funkcjonowały w środowisku antiocheńskim i co mogą one powiedzieć o przyczynach wygnania Jana z Konstantynopola?

przyp. P. Sz.] jako pomocnik lub jeden z pomocników biskupa przy pełnieniu jego liturgicznych, duszpasterskich i administracyjnych obowiązków".

71 Por. Cavallera, Le schisme d'Antioche, s. 262; Mayer, Antioch and the West, s. 5-32.

72 Szerzej na ten temat zob. obszerną monografię poświęconą prawie w całości duszpasterskiej działalności Jana Chryzostoma w Antiochii: P. Rentinck, La cura pastorale in Antiochia nel IV secolo, Roma 1970; oraz przyczynki: P. Allen - W. Mayer, Through a bishop's eyes: towards a definition of pastoral care in Late Antiquity, ,Augustinianum” 40 (2000) 345-397, zwł. 361-378; Mayer, Patronage, pastoral care, s. 61-67.

${ }^{73}$ Por. Sozomenus, HE VIII 3, GCS NF 4, 352-353, Kazikowski s. 525-526: „Tymczasem Jan, skoro tylko stanął u steru swych biskupich rządów, podjął przede wszystkim usilne starania o poprawę stylu życia podlegających pod jego władzę duchownych. Wydobył na wierzch zarówno ich tryb postępowania na co dzień, jak i szczegółowo przebadał cały kierunek religijnego wychowania, a jednocześnie wykazywał winy i odwodził od błędu; niektórych nawet usunął z Kościoła. $\mathrm{Z}$ natury bowiem usposobiony krytycznie i pełen uzasadnionego oburzenia na krzywdzicieli, pełniąc obowiązki biskupa jeszcze więcej dawał upust tego rodzaju skłonności i uczuciom. Wszak wrodzone usposobienie w połączeniu ze swobodą działania bez trudu nakłaniało język do argumentacji i jeszcze prędzej wyzwalało falę gniewu na tych, co grzeszą". 
Pierwszym czynnikiem łagodzącym zaistnienie konfliktu jest fakt, że Jan, pomimo tego, że w Antiochii wykonywał czynności i pełnił funkcje quasiepiskopalne, jednak nie był biskupem i nie mógł działać zgodnie z takim autorytetem, jakim cieszył się biskup. Jego rolą było jedynie asystowanie Flawianowi w obowiązkach biskupich. W konsekwencji, dopiero w Konstantynopolu mógł w pełni przeżyć i wcielić w życie wyobrażenie roli biskupa, jakie ukształtował sobie wcześniej w Antiochii. Palladiusz sugeruje, że w Konstantynopolu Jan postrzegał siebie jako osobę kształtującą idealny wzór stylu życia biskupa ${ }^{74}$. Również szeroko zakrojone reformy Jana ${ }^{75}$, które rozpoczął po objęciu tronu biskupiego sugerują, że miał jasno zdefiniowany pogląd na to, jak powinna funkcjonować domena biskupia, jej kler i poszczególne agendy kościelne. Był to ideał, do którego jednak rzeczywistość zupełnie nie dorastała. Z wypowiedzi Palladiusza wynika, że Jan Chryzostom każde swoje działanie jako biskupa, postrzegał jako wzór dla innych ${ }^{76}$. Postawa taka prawdopodobnie miała wpływ na trudności, których doświadczał w Konstantynopolu. Nie należy jednak przyjmować, że nie miał ich w Antiochii. Jeśli weźmie się pod uwagę fakt, że Jan przygotowywał się do realizacji swej „filozofii” episkopatu nie w Konstantynopolu, lecz w Antiochii, to należy zauważyć, że już w czasie jego prezbiteratu mógł popadać w mniejsze lub większe konflikty z ludźmi, z którymi pracował. Przykładowo, przysposabiając się do przejęcia urzędu po Flawianie, starał się też prowadzić życie ascetyczne (czego wymagał od innych), a swoje de facto episkopalne obowiązki wykonywał w sposób zgodny ze swoją „filozofią" episkopatu. Podobnie jak w Konstantynopolu, irytowało to niektórych arystokratycznych patronów fakcji oraz wielu innych prezbiterów i diakonów, którzy nie podzielali tego samego ideału. Z pojawiających się w kazaniach antiocheńskich oskarżeń laikatu np. o noszenie zbyt modnych szat oraz oskarżania niektórych duchownych np. o podejrzane interesy i nadużycia finansowe ${ }^{77}$, można wyciągnąć wniosek, że nie wszyscy świeccy i nie całe duchowieństwo antiocheńskie podzielało ideał promowany przez Jana oraz, że niektórzy z członków kleru prowadzili życie podobne do tego, z jakim zetknął się później wśród duchownych Konstantynopola.

Drugim czynnikiem łagodzącym reakcję na kazania Jana była nieobecność w Antiochii, przynajmniej w okresie, gdy Jan był tam prezbiterem, wschodniego dworu cesarskiego. $\mathrm{Z}$ tego względu np. jego głębokie przekonanie o wyższości władzy kapłańskiej nad cesarską ${ }^{78}$, prawdopodobnie nie mogło przy-

${ }^{74}$ Por. Palladius, Dialogus 17.

75 Szczegóły reformy wymienia Palladiusz w Dialogus 5.

76 Por. Palladius, Dialogus 17.

77 Por. np. In epistulam I ad Corinthios hom. 21, 6, PG 61, 179; In epistulam ad Philippenses hom. 9, 4, PG 62, 251.

78 Por. In Matthaeum hom. 82, 6, PG 58, 744-745, tłum. J. Krystyniacki: Św. Jan Chryzostom, Homilie na Ewangelię wedtug św. Mateusza, oprac. A. Baron, II, ŹMT 23, Kraków 2001, 462, gdzie 
sporzyć mu zbyt wielkich problemów w czasie, gdy sam nie był biskupem, a cesarz i jego przedstawiciele znajdowali się daleko. Również inne trudności, których Jan doświadczał z powodu bliskości cesarza, jak np. konflikt wynikający z walki o patronat bogatych i wpływowych członków klasy senatorskiej w Konstantynopolu, a poprzez nich cesarza ${ }^{79}$, miały mniejsze prawdopodobieństwo zaistnienia w Antiochii.

Trzecim czynnikiem łagodzącym zaistnienie konfliktu może być schizma, trwająca w Antiochii od dłuższego czasu. Ponieważ sfera działalności Jana w Antiochii dotyczyła jedynie części (nawet jeśli była to większa część) nicejskiej społeczności w mieście, należy pamiętać, że liczba patronów i sieć ich powiązań, na których opierała się fakcja, była siłą rzeczy stosunkowo ograniczona. Implikacje wynikające z tego są szczególnie widoczne, gdy spojrzy się na potencjalnie korzystne stosunki, którymi nie mogła pochwalić się melecjańsko-nicejska fakcja, do której należał Jan, a którymi dysponował mniejszy odłam nicejczyków, któremu przewodził Paulin. Przykładowo, jednym z bardziej znaczących i zamożnych patronów tej grupy był pochodzący z rodziny antiocheńskich kuriałów Ewagriusz $(\dagger 394)^{80}$, którego brat był członkiem senatu w Konstantynopolu. Sam Ewagriusz spędził 10 lat w Italii, gdzie nawiązał wpływowe stosunki w Kościele Zachodnim (m.in. z papieżem Damazym). Po powrocie do Antiochii gościł wielu bogatych i wpływowych chrześcijan z Zachodu, którzy w czasie trwania schizmy popierali paulinian. Po długim okresie aktywnego wspierania fakcji, Ewagriusz sam został jej biskupem $(388)^{81}$, a święceń - z pogwałceniem kanonów - udzielił mu umierający Paulin ${ }^{82}$. Przypadek Ewagriusza jest najlepiej znany, ale nie jedyny. Należy więc wziąć pod rozwagę, że nawet jeśli Antiochia była ważnym miejscem rozgrywania spraw kościelnych i politycznych, to zakres wykonywanych przez Jana obowiązków quasi-episkopalnych był dość ograniczony. Dla prze-

Jan Chryzostom mówi do prezbiterów udzielających Komunii, aby w przypadku zauważenia osoby niegodnej, obciążonej grzechami, nie dopuścili jej do Stołu Pańskiego: „Choćby był on jakimś wodzem, choćby namiestnikiem, niechby nawet [był to] ten, którego skronie zdobi korona, lecz niegodnie przystępuje - nie dopuść go, bo ty masz większą moc niż on”.

79 Por. D. Caner, Wandering, Begging Monks: spiritual authority and the promotion of monasticism in Late Antiquity, Berkeley 2002, rozdział V, który wykazuje, że jedną z przyczyn konfliktu między Janem a Izaakiem w Konstantynopolu było zorganizowanie przez Izaaka i jego mnichów odrębnej sieci patronatu i ich niezależna opieka nad ubogimi. Próby Jana, aby fundusze Olimpii skierować na bezpośrednią pomoc ubogim, stały w sprzeczności do interesów innych episkopalnych klientów i niektórzy z nich z czasem okazali się wrogami Jana (np. wspominany już Epifaniusz z Salaminy); zob. też Palladius, Dialogus 17, SCh 341, 348.

${ }^{80} \mathrm{Na}$ temat Ewagriusza zob. F. Drączkowski, Ewagriusz $z$ Antiochii, EK IV 1372; J. Gribomont, Evagrio di Antiochia, DPAC I 1311

${ }^{81}$ Por. Socrates, HE V 15; Sozomenus, HE VII 15; Mayer, Antioch and the West, s. 5-32; S. Rebenich, Hieronymus und sein Kreis. Prosopographische und sozialgeschichtliche Untersuchungen, Stuttgart 1992, 52-75.

${ }^{82}$ Por. Theodoretus, HE V 23; Kelly, Ztote usta, s. 112. 
ciwwagi, należy także pamiętać, że w Konstantynopolu ortodoksyjna wspólnota nicejska, której Jan przewodził, również nie obejmowała wszystkich mieszkańców miasta i od dawna współzawodniczyła z mającą taki sam status społecznością nowacjan ${ }^{83}$, której przewodził szanowany i charyzmatyczny biskup Sysyniusz ${ }^{84}$.

Jak więc łatwo zauważyć, praca duszpasterska Jana w Antiochii i Konstantynopolu, pomimo tego, że prowadzona była niemalże w tym samym stylu, to jednak z powodu specyficznych uwarunkowań charakterystycznych dla każdej ze starożytnych metropolii, przynosiła różne efekty i powodowała odmienne reakcje.

Pomimo pobieżności niniejszego studium, trzy zaprezentowane tu kwestie okazują się mieć ważne znaczenie dla zrozumienia okoliczności związanych z wyborem i pełnieniem przez Jana funkcji biskupa. Badając fakty historyczne w szerszym kontekście, a zwłaszcza z uwzględnieniem wydarzeń rozgrywających się w Antiochii - co daje nowy wgląd w ich przebieg - można się przekonać, że tradycyjny obraz powinien być traktowany z ostrożnością. Spojrzenie poza obraz prezentowany przez źródła, prowadzi do odnalezienia konkretnych sugestii co do tego, że sytuacja Jana w Antiochii nie była, jak twierdzi Teodoret z Cyru, „pomyślną żeglugą”. To z kolei prowadzi do konkluzji, że źródła powinny być traktowane z większą dozą ostrożności. Ponadto logiczne i proste rozgraniczenie pomiędzy życiem Jana w Antiochii i w Konstantynopolu, przeważające we współczesnej literaturze, wynika bardziej z dosłownego odczytywania źródeł niż z rzeczywistości. Jak widać, rezultaty badań modyfikują powszechnie przyjmowany wizerunek i domagają się poświęcenia większej uwagi czasowi pobytu i działalności Jana w Antiochii, co z kolei może być kluczem do wyjaśnienia wielu wydarzeń, które miały miejsce w czasie późniejszym w Konstantynopolu.

${ }^{83}$ Nowacjanie w 2. poł. IV wieku mieli w Konstantynopolu własnego biskupa i kilka świątyń, por. Kelly, Ztote usta, s. 137.

${ }^{84}$ Por. Kelly, Ztote usta, s. 137-139. 


\section{L'ÉLECTION ET LA DÉPOSITION DE JEAN CHRYSOSTOME, ÉVĘQUE DE CONSTANTINOPLE. L'ESSAI DE REINTERPRETATION DES TRA- DITIONS HISTORIQUES}

(Résumé)

Dans cet article, on a fait un essai de réinterprétation des textes originels et de leur présentation dans un contexte plus large, surtout celui qui prend en considération les évènements qui ont eu lieu à Antioche. Voici les trois questions qui y ont été présentées:

1. L'élection de Jean comme évêque de Constantinople dans le contexte de l'élection épiscopale de ses prédécesseurs (Nectaire et Eudoxe) et les évènements qui ont eu lieu à Antioche;

2. Les rapports d'Epiphane, évêque de Salamine, avec Jean Chrysostome traités également dans le contexte des relations d'Epiphane avec les évènements d'Antioche;

3. Le caractère de la pastorale de Jean Chrysostome à Antioche (en tant que presbytre) et à Constantinople (en tant qu'évêque).

L'analyse des textes originels dégage l'idée que l'image traditionnelle des évènements en question doit être traitée avec précaution. Un regard qui dépasse celui présenté par les sources conduit à la recherche de suppositions concrètes que la situation de Jean à Antioche, selon Théodoret de Cyr, n'était pas „une navigation favorable". Cela conduit à la conclusion que les sources, et surtout Dialogus de vita Ioannis Chrysostomi de Palladius, doivent être traitées avec une plus grande dose de précaution. Les résultats de la recherche sont modifiés par le portrait reconnu et ils exigent une attention plus importante consacrée au temps de séjour et aux activités de Jean à Antioche. Tout cela peut être une clé pour éclairer beaucoup d'évènements qui ont eu lieu plus tard à Constantinople. 